\title{
RECENT NESTING OF THE CASPIAN TERN AT EGG ISLAND, LAKE ATHABASCA, ALBERTA
}

D.V. CHIP WESELOH, Provincial Museum, Edmonton, Alberta* and LEWIS COCKS, Canadian Wildlife Service, Edmonton, Alberta.

In 1952 approximately 20 pairs of Caspian Terns were discovered nesting with California and Herring Gulls on what is now known as Egg Island in Lake Athabasca in northeastern Alberta. ${ }^{9} 1011$ That was the first documented nesting site for this large tern in Alberta.

Since 1952 there have been no accounts published of the status of the Caspian Terns on Egg Island. Neither Salt \& Wilk nor Salt \& Salt reported more recent nesting. ${ }^{10119}$ In fact, the former seemed to indicate that 1952 was the only year when nesting was reported. For the period 1961 to 1970 , Sadler and Myres reported of the Caspian Tern: "no recent breeding records from Alberta." ${ }^{8}$ We conclude that since 1952 the breeding status of the species in Alberta is unknown.

On 15 June 1977, we flew to Egg Island to collect California Gull eggs for toxic chemical analysis and also to document the current status of the Caspian Tern on the island.

We arrived at the island by float plane at 1345; California Gulls, Herring Gulls and Caspian Terns were immediately obvious. The terns were congregated near the centre of the island, on the area of highest elevation and directly below and sur-

* Present Address: Canadian Wildlife Service, Canada Centre for Inland Waters, P.O. Box 5050, Burlington, Ontario, L7R $4 A 6$. rounding a navigational tower (see photo). A systematic search by DVW revealed 47 Caspian Tern nests in that area; a total of 59 Caspian Terns were counted on and around the island. Most tern nests contained two eggs; some had one, others three. The nests were mere scrapes (depressions) in the loose cobblestone substrate and had no nest material. Before we left the island (at 1420), DVW estimated a maximum of 100 pairs of California Gulls. Their nests were distributed primarily to the south of the tern nests on less elevated areas. We counted only nine Herring Gulls on the island and located only.one active nest. It was on the southeast portion of the island.

Egg Island is elliptical (with the long axis oriented NW-SE), and approximately $70 \mathrm{~m}$ long. Its highest point, approximately $2-1 / 2 \mathrm{~m}$ above lake level, is just NW of the centre, where a tall, metal navigational tower is located. The island is devoid of herbaceous vegetation except for a small patch of shrubs (species undetermined) near the SE end. The entire surface of the island consists of fistsized, gray cobblestones. Several partially obliterated terraces were visible on the island, undoubtedly the work of wave and ice action over the years.

When we flew over Egg Island at approximately $100 \mathrm{~m}$ on our initial approach, we found it hard to see 


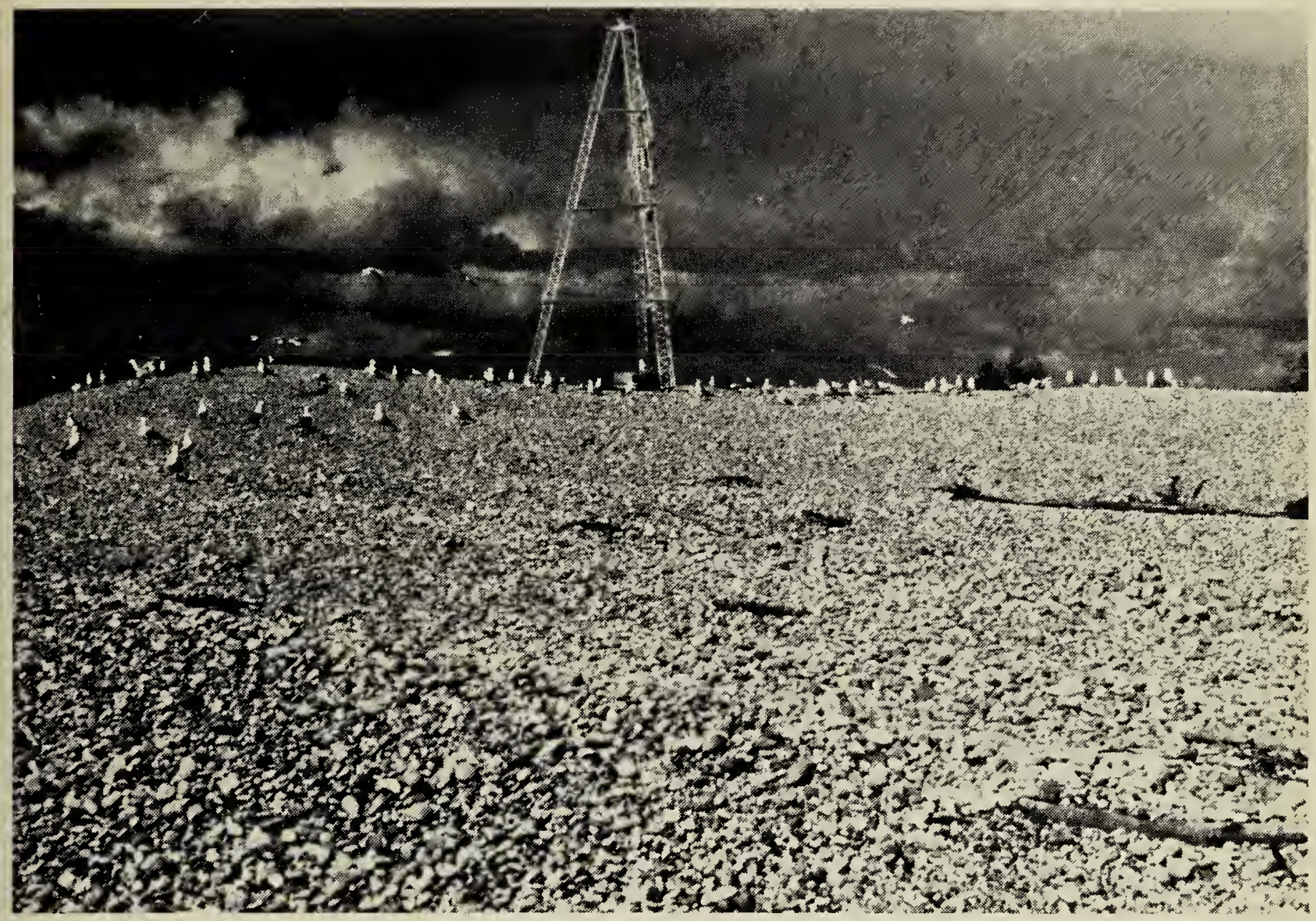

Egg Island, Lake Athabasca, Alberta. Caspian Terns nest beneath and to the right (east) of the tower.

Chip Weseloh

gulls or terns sitting on the island; neither of us were sure that we had seen any! On our departing pass over the island we still found it difficult to locate individual birds that we knew were there. They blended almost perfectly with the cobblestones.

The history of the Caspian Tern in Alberta prior to 1952 is sporadic, but overwhelmingly indicates that the bird was most commonly seen in the Lake Athabasca area. Preble recorded several birds at the Lake Athabasca Delta on 2 June $1903 .^{6}$ Seton recorded it ". . but once in the Delta" on 4 June 1907 and speculated that "This seems to be one of its breeding stations." 12 Soper gave sight records for the Delta in late May, 1932 and 28 June $1933 .{ }^{13}$ In southern Alberta, Taverner speaks of only occasional sight records on the Prairie Provinces and neither Farley nor Rand observed the bird. ${ }^{15} 27$

Of his initial discovery of the nesting colony at Egg Island, B. Wilk writes (in litt.),

"... the date of my visit to the island ... was 18 June 1952. On that date two specimens were taken-one a female off a nest and the other an adult male, from the size of the testis it was a non-breeder. If I remember correctly the birds had eggs at the time.

"The island at the time was known as Burntwood Island-I well remember the terraces and the bleak appearance of the island but it seems to me that there was some plant covering, laborador tea, etc.

"The reason I went to the island was to confirm a sighting by one of the early explorers-perhaps Preble. I believe I was the first to report the nesting. I'm sure there weren't 47 nests when I was there. I would venture a guess of perhaps about 25."

Since 1952, records of Caspian 
Terns have been less sporadic and more widespread. Stirling listed the Caspian Tern as an occasional migrant in the Calling Lake area prior to $1955 .{ }^{14}$ Two individuals were seen at Beiseker on 2 April 1958. ${ }^{4}$ Single birds were reported at Medicine Hat on 9 August 1967 and at Cold Lake on 12 July $1968 .{ }^{8}{ }^{1}$ For the period 1969 1972, Hohn regards it as a fairly rare summer visitant in the Peace-Athabasca Delta and as a breeding summer resident in the Lake Athabasca Region. ${ }^{3}$ In the 1970 s additional sight records have been made during migration along the Athabasca River north of Ft. McMurray (R. Palindat, personal comm.), in the Rocky Mountains near Kananaskis (M. McNicholl, personal comm.) and in southern Alberta. ${ }^{5}$

In contrast to the increase in reports of Caspian Terns in southern Alberta since 1952, reports on the status of the nesting colony in Lake Athabasca have been few. O. Hohn visited Egg Island on 2 July 1971 and reported (in litt.),

"Caspian Terns were nesting. Some nests still held eggs, most of them 1, 2 or 3 downies. I estimated there were a little over 20 pairs of terns and 50-80 pairs of California Gulls which were also nesting-downy young were seen."

O. Hohn also reported sight records on the south shore of the lake on 26 and 27 July 1971. A.R. Smith (personal comm.) flew over the island in early June and July of 1975 and photographed it. Large, white birds, evenly distributed as if on territory, are visible in the photograph (when viewed under a dissecting microscope) though they were not seen from the air. In 1976 G.R.A. Ebel (personal comm.) working in western Lake Athabasca, frequently observed Caspian Terns but was unable to visit Egg Island.

Concerning the possibility of other
Caspian Tern nesting colonies in the Lake Athabasca area, Ebel writes (in litt.),

"There exists at least two colonies other than the Egg Island colony in the Peace-Athabasca Delta. One small colony of 8-9 pairs exists on the northwest shore of "Slough Lake" (local name Frezie Lake). This lake may be located east of the mouth of Jackfish Creek (Richardson Lake) across the Athabasca River.

"The other colony is at Beartooth Island which is near the mid-west end of Lake Athabasca. There are approximately 30 pairs. The Indians have been taking eggs from this island for years."

Neither we, nor Ebel, have personal experience with these two colonies; Ebel learned of them from local people. Nor have we ever seen any other reference to them. These nesting areas remain to be confirmed.

In conclusion, we concur with $\mathrm{O}$. Hohn (in litt.) on the status of the Caspian Tern on Egg Island.

"My opinion is that it breeds annually on Egg Island and has almost certainly done so since at least the beginning of the century."

We believe that the failure to observe terns (or gulls) on the island during Smith's recent overflights was due to the superb camouflage of the birds against the island's surface.

We thank Martin McNicholl and Charles Dauphine for comments on an earlier version of this manuscript.

'BLOKPOEL, H. and F.L. WAITE. 1970. Birds observed in the area around Cold Lake, Alberta. Unpubl. Ms. 14 pp.

${ }^{2}$ FARLEY, F.L. 1932. Birds of the Battle River region. Inst. of Applied Art Ltd. Edmonton. 85 pp.

${ }^{3} \mathrm{HOHN}$, E.O. 1973 . The birds of the PeaceAthabasca Delta and of the Lake Athabasca region. Canadian Wildlife Service. $32 \mathrm{pp}$. 
${ }^{4} \mathrm{HOHN}$, E.O., W.R. SALT and E.D. BEACHAM. (Eds.) 1958. Alberta bird report for 1958. $11 \mathrm{pp}$.

${ }^{5}$ LANG, B., and B. DANIELSON (compilers). 1973. Natural history observation. Part I. Birds. Calgary Field Naturalist 5(4): 143-151.

${ }^{6}$ PREBLE, E.A. 1908. A biological investigation of the AthabascaMackenzie region. N. Am. Fauna 27. $574 \mathrm{pp}$.

'RAND, A.L. 1948. Birds of southern Alberta. Nat. Mus. Canada Bull. 37, Biol. Ser. 37. $105 p p$.

${ }^{8}$ SADLER, T.S., and M.T. MYRES. 1976. Alberta birds, 1961-1970, with particular reference to migration. Prov. Mus. Alberta, Nat. Hist. Sec., Occas. Papers 1. 314 pp.
9SALT, W.R. and J.R. SALT. 1976. The birds of Alberta with the ranges in Saskatchewan and Manitoba. Hurtig Publishers, Edmonton. 488 pp.

${ }^{\circ}$ SALT, W.R., and A.L. WILK. 1958. The birds of Alberta. Dept. of Economic Affairs, Edmonton. $511 \mathrm{pp}$.

"SALT, W.R., and A.L. WILK. 1966. The birds of Alberta. 2nd revised edition. Queen's Printer, Edmonton. 512 pp.

${ }^{12}$ SETON, E.T. 1911. The Arctic Prairies. C. Scribner \& Sons, N. Y. 415 pp.

${ }^{13}$ SOPER, J.D. 1942. The birds of Wood Buffalo Park and vicinity. Trans. Royal Can. Inst. 24:19-97.

${ }^{14}$ STIRLING, David. 1962. Athabasca bird checklist. 2 pp. mimeo.

${ }^{15}$ TAVERNER, P.A. 1934. Birds of Canada. Nat. Mus. Canada Bull. 72:1-445.

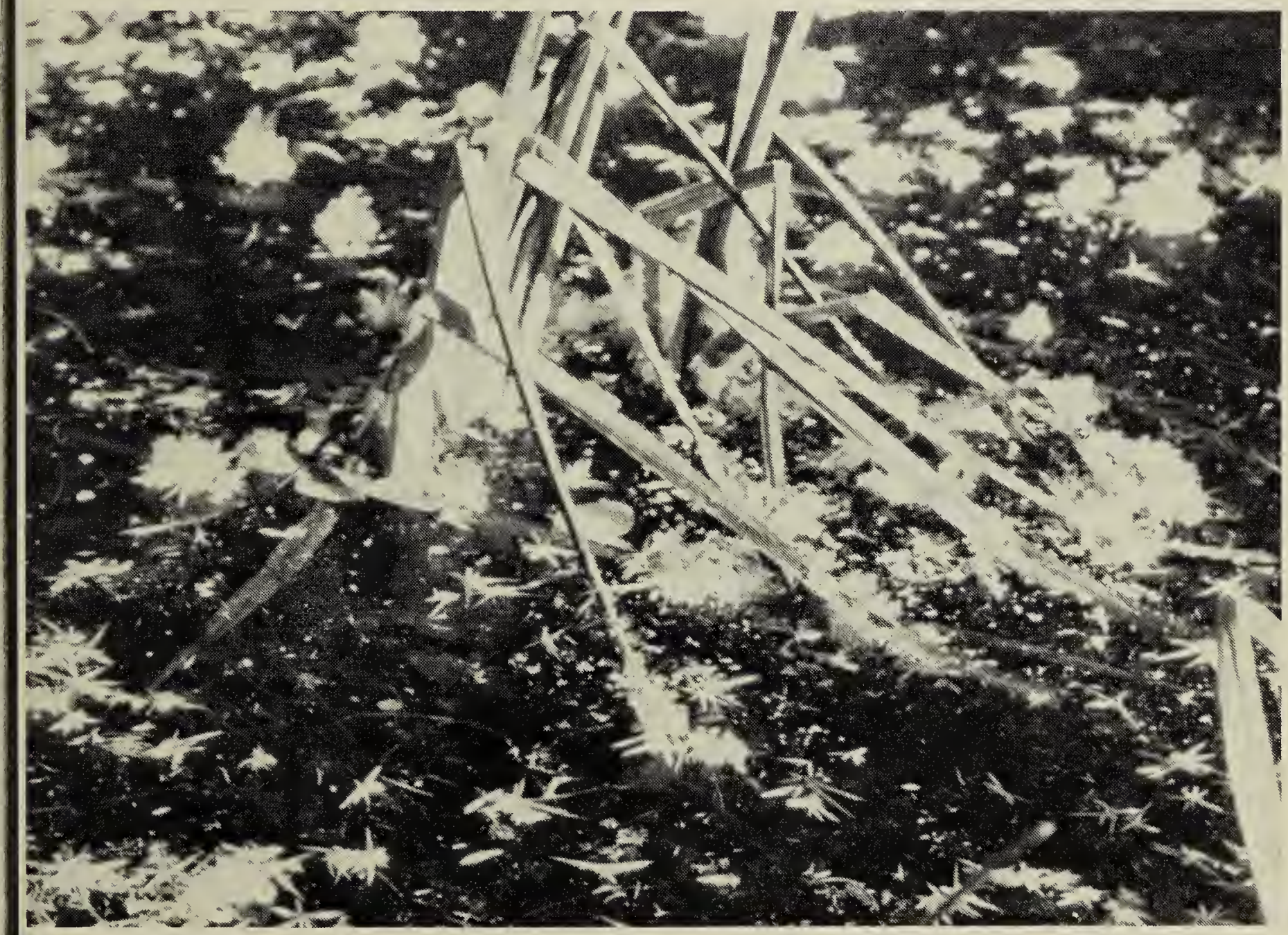

Frost crystals forming on ice.

Fred W. Lahrman 